\title{
Comparative assessment of Islamic and traditional banking in the context of their sustainability
}

\author{
Magomed Tashtamirov $^{1^{*}}$, Milana Abdurakhmanova ${ }^{2}$ \\ ${ }^{1}$ Chechen State University, 364060, A. Sheripova Str., 32, Grozny, Russia \\ ${ }^{2}$ Grozny state oil technical university named after academician M.D. Millionshchikov, 364051, H.A. \\ Isaev Ave., 100, Grozny, Russia
}

\begin{abstract}
The development of banking in particular, and the financial system as a whole, is associated with many transformations and transformations that relate not only to certain aspects of the activities of financial institutions, but also to the processes of forming new models for organizing financial transactions. One of these models is the Islamic system of organizing financial activities, which has been actively developing over the past 30 years. However, the question of comparing Islamic finance and the traditional approach to organizing banking activities in terms of their efficiency, stability and liquidity remains open. This study is aimed at identifying and systematizing the main approaches to the comparative assessment of the effectiveness of the two models of financial activity. As a result of the study, it was revealed that the Islamic bank has both differences from traditional banking institutions, which is associated with the specifics of individual states and the architecture of national banking systems, and similar identical characteristics, which indicate an insignificant difference in the efficiency and sustainability of the two models.
\end{abstract}

\section{Introduction}

Researches devoted to the effectiveness of banking interest a wide variety of scientists and professionals for a long time. At the macro level, there is evidence that economic growth is positively associated with the efficiency of the banking sector. At the micro level, efficiency studies provide comparative information that will be of interest to bank managers and policymakers in order to improve the efficiency of the banking system. Banking performance and related with it dynamics are closely linked to banking risks and capitalization, while everincreasing competition in the financial services sector makes efficiency a top priority for bank managers, regulators and policymakers.

If we consider various approaches to the comparative assessment of the effectiveness of a particular banking system, then the researches were based on comparing the national banking systems of different countries, methods of monetary and macroprudential regulation, general macrobanking policy, or comparing multi-level and single-level types of banking

*Corresponding author: basxo@yandex.ru 
systems. However, in recent years, scientific interest in the type of Islamic banking system continues to grow, which was originally formed in the countries of the Islamic world, but is increasingly increasing its expansion in the secular states of developing and developed national economies.

Taking into account the fundamental principles of the functioning of Islamic financial institutions, there is an objective expediency to use the expanding experience of this model of financial activity in order to ensure sustainable dynamic development of individual national economies and their territorial units in the form of subjects of the country. An important aspect in this case is the need for researches aimed to identifying the features of the development of the Islamic finance industry in the world economy in comparison with the general trends in the development of traditional models of banking.

\section{Trends in the Islamic finance industry and traditional banking}

Islamic banks strengthened their presence in the global financial system with total assets under management of about \$ 2.9 trillion in 2019, while maintaining double-digit annual growth rates even in the face of the financial crisis and political turmoil (Fig. 1). Taking into account the current trends in the development and scaling of Islamic financial institutions in the world, by 2024 the projected volume of the total assets of the Islamic sector will be about 3.7 trillion. US dollars.

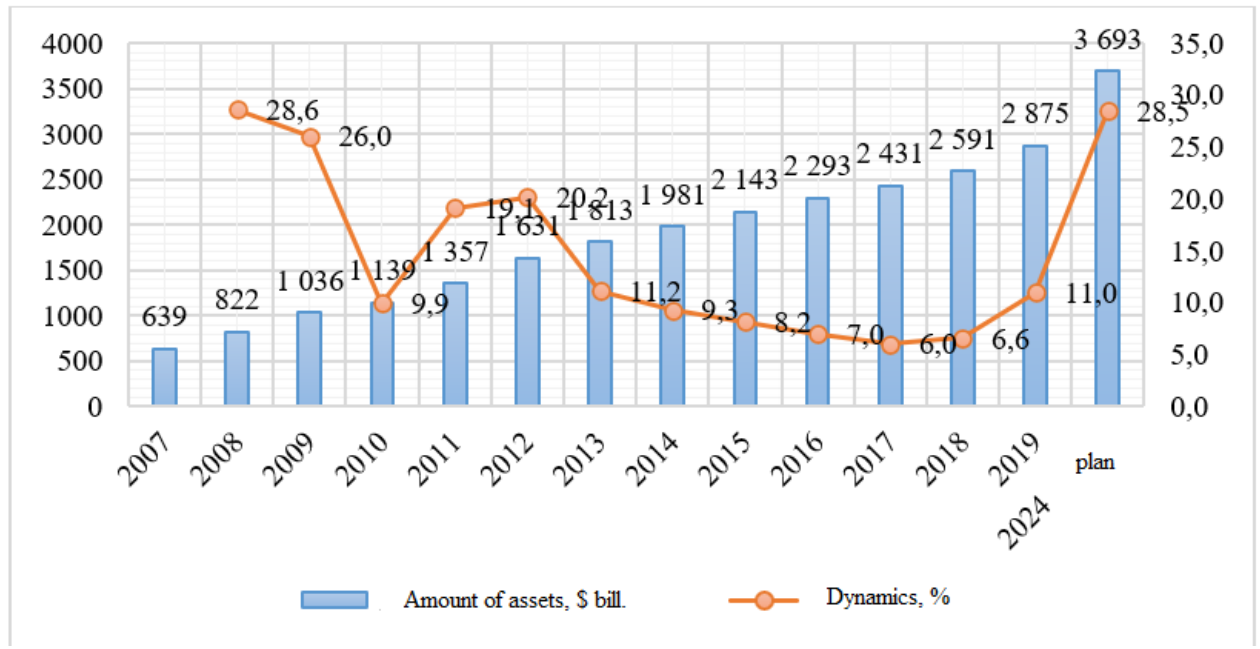

Fig. 1. Dynamics of Islamic financial assets in the global world [1]

Islamic banking (IB) practically does not exist in Western countries, but is an important aspect in several countries of North Africa, Central and Far East Asia, where it usually accounts for more than $20 \%$ of the assets of the banking system. 


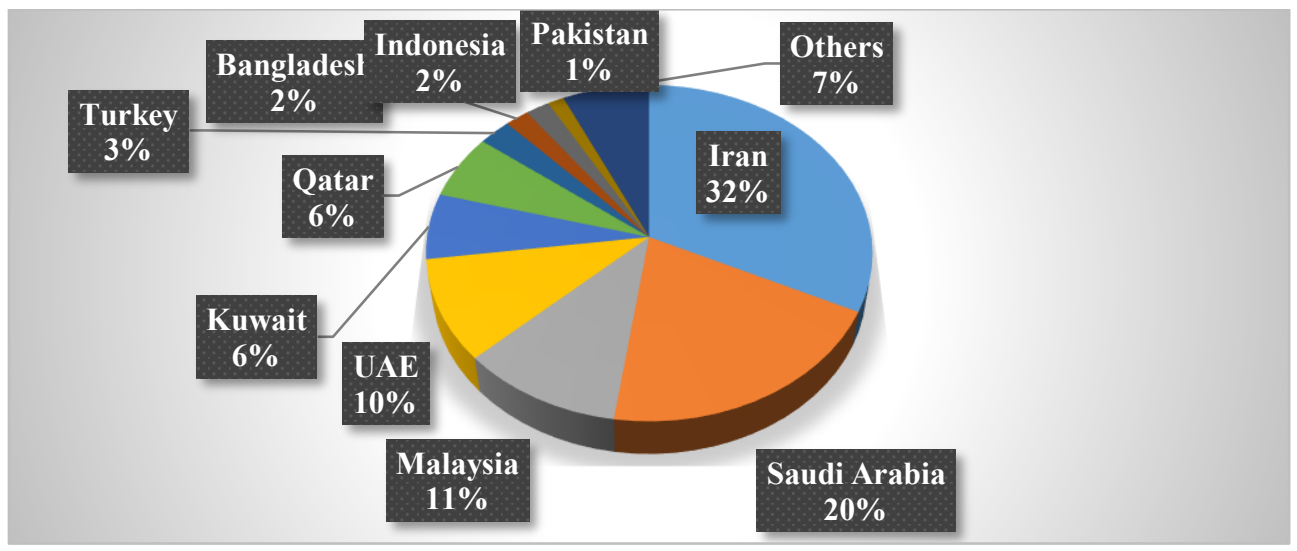

Fig. 2. Share of global Islamic banking assets by country [2]

As for the leading Islamic banking asset jurisdictions, according to Figure 2, Iran retained its historical position as the largest market, accounting for $32.1 \%$ of the global Islamic banking industry. This is followed by Saudi Arabia at 20.2\%, Malaysia at $10.8 \%$, the UAE at $9.8 \%$ and Kuwait at $6.3 \%$, which round out the top five. In 2019, Malaysia, in particular, saw an increase in the estimated share of the Islamic finance market by about $71 \%$, which has become a key driver of the growth of Islamic finance in the region. Other countries in the top 10 Islamic banking jurisdictions by size are Qatar, Turkey, Bangladesh, Indonesia and Bahrain.

When comparing Islamic and traditional banking, it is important to take into account such factors as: the duration of development in history, the geographical coverage by territories and countries, the total size of assets, the rate of dynamics, the level of stability in crisis conditions, profitability and efficiency. In terms of the volume of assets, it is quite clear that the Islamic financial industry cannot be compared to the volume and scale of assets that traditional banks have at their disposal.

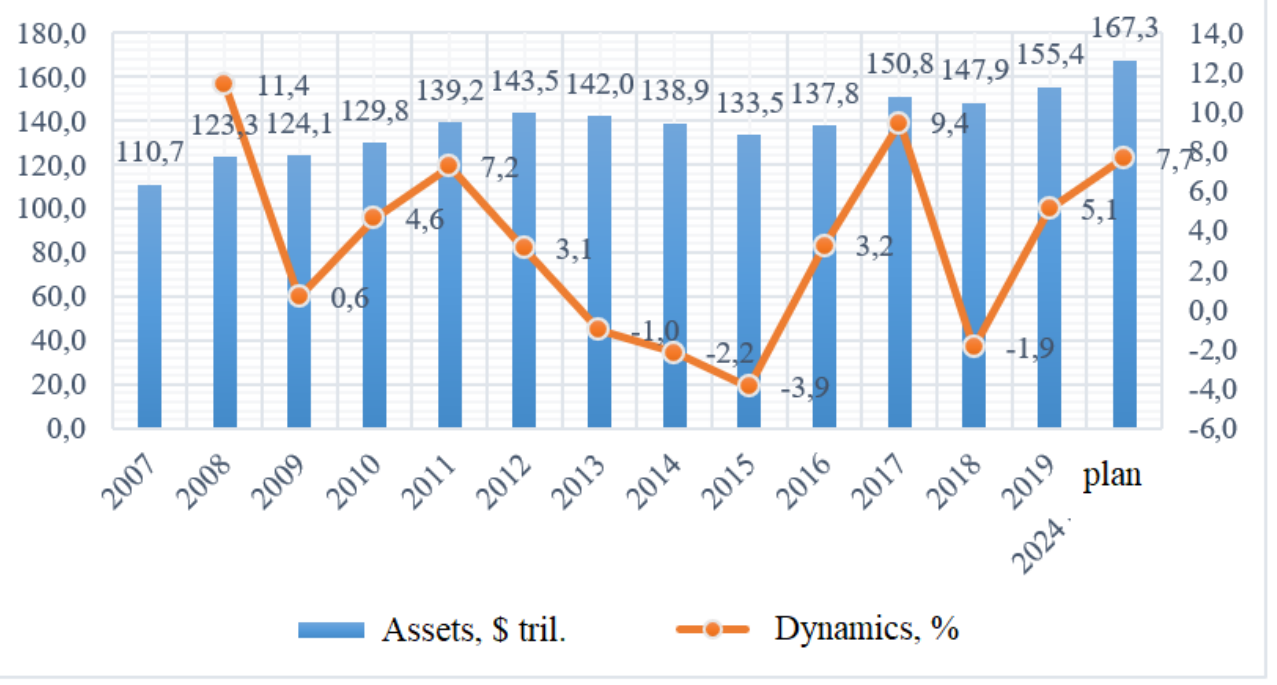

Fig. 3. Dynamics of global banking assets for the period 2007-2019, trillion. US dollars [2]

The global dynamics of total banking assets reflects the colossal gap in the scale of the banking services market between the Islamic and traditional models, as shown in Figure 3. 
A distinctive feature is the nonlinear trend in the development of the world banking system, which has both recessions and significant growth. Thus, the average value of the growth rate of assets of the Islamic financial industry for the period $2007-2019$. is $14.7 \%$, with $3.3 \%$ in the traditional model of banking. Thus, the dynamics of growth of Islamic financial assets is growing linearly and at a more intensive rate in comparison with the global traditional banking system. If we consider the change in the share of Islamic financial assets in the overall structure of total banking assets, then a systematic growth can be traced (see Fig. 4).

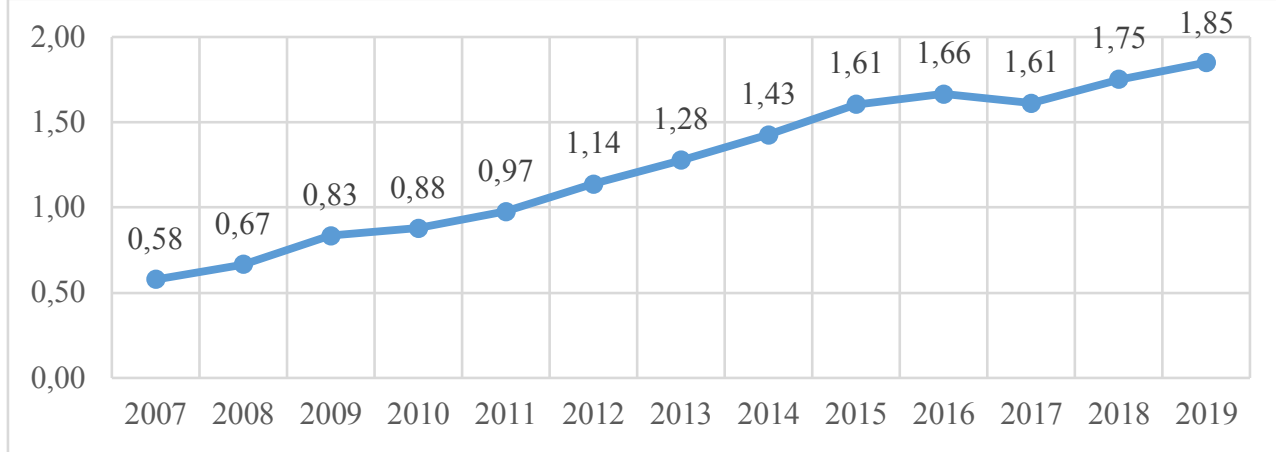

Fig. 4. The share of Islamic financial assets in the global banking system for the period 2007-2019

Every year, there is an increase in the Islamic finance industry in the total volume of global banking assets, whose share at the end of 2019 was $1.85 \%$. This increase is due to the fact that the rate of growth of Islamic finance in the world is much higher than that in traditional banking.

\section{Comparative assessment of banking models}

Islamic banks, although often small in size, have managed to withstand the local competition they face with their traditional banking counterparts. At the heart of the success of Islamic banks is their unique business model, which prohibits the payment of interest on debt obligations, complex derivatives, short selling, speculation and investment in certain areas (largely considered unethical). In addition, the financial products of Islamic banks are built on the concept of risk sharing between providers and users of funds, which, apparently, stimulates responsible behavior that reduces credit risk [3].

The requirement for transactions to be backed by tangible assets brings Islamic banks closer to the real economy than conventional banks, and this was important in the postfinancial crisis era. The choice of Islamic or traditional banking products is entirely up to the investor, although investors from Muslim countries are expected to opt for the former. However, choosing Islamic or conventional banking in itself can be informative for investors. For example, investors in Saudi Arabia welcome the use of Islamic bank financing by listed companies [4]. In addition, firms issuing Islamic bonds can pay a lower coupon than an equivalent conventional issue [5]. In general, Islamic finance investors may be willing to incur additional costs for "psychic dividends" [6].

A number of studies comparing the performance of the Islamic and traditional banking sectors have found significant performance gaps between the two types of banks at specific points in time and across multiple countries. Given the observed differences between the business models of Islamic and traditional banking, changes in efficiency dynamics are likely to be expected. However, the underlying dynamics of this efficiency has hardly been investigated. 
Among the many common characteristics that the research aims to show, it can be noted that Islamic banks are: more profitable, have superior asset quality and capitalization; have a similar risk profile to their traditional counterparts; and demonstrate higher technical efficiency. This does not mean that Islamic banks are immune to economic shocks, but they are more muted.

A distinct Islamic profile has been argued to enhance diversification opportunities for investors. [7] Conversely, some Islamic stocks can be negatively affected by religious restrictions on stock trading [8]. Moreover, Islamic banks are particularly interested in development and economic prosperity in low-income countries. This can be partly explained by their relatively higher level of liquidity.

In terms of corporate governance, Islamic banks generally adhere to the Sharia Supervisory Board (SSB), which, working in conjunction with the board of directors, is considered to be the "Supervisory Board". Companion studies show that higher SSB is associated with improved financial performance and acts as a protective cushion against risk [9]. However, it is known that the dual structure of Islamic banks reduces their profitability.

From the point of view of assessing the effectiveness of Islamic and traditional banks through the prism of their stability and convergence, certain similarities and differences have been identified depending on countries and formed models of banking systems. More financially aligned banking systems are characterized by financial depth, business transparency, a stable economic environment, and concentrated banking systems. Individual banks operating within the agreed banking systems have more diversified sources of income, higher liquidity, profitability and financial stability [10]. Islamic banks generally mimic conventional banks. Given that similarities exist only in some countries, it can be assumed that behavior may not be due to imitation, but to other factors, such as regulatory / corporate, economic, and bank-specific characteristics.

Taking into account the positive relationship between the development of the banking system and economic growth in national economies, it is determined that the development of Islamic finance (as measured by loans issued by Islamic banks) is positively correlated with economic growth. When it comes to the impact of institutional quality on the relationship between Islamic finance and economic growth, the results show a negative impact on interactions, suggesting that while Islamic financial development has a positive impact on the economy, an underdeveloped institutional framework will mitigate this positive impact. As a result, countries seeking to accelerate economic growth through the development of Islamic banking also need to introduce appropriate legislation, regulation and supporting infrastructure [11]. Given this circumstance, it is important to note that numerous attempts to attract Islamic financial assets to the Russian economy, which was described in scientific works and in the practical environment [12], were in vain solely for the above reason. Taking into account the specifics of the work and the conditions for the stable functioning of the Islamic model of financial activity, it is necessary to initially ensure the formation of the entire institutional framework for the operation of this type of financial institutions.

One of the fundamental aspects of ensuring the stability and reliability of a commercial bank and any financial institution is the capital adequacy ratio, which, according to the Basel III standard, should be at least $8 \%$, while in Russian practice in relation to systemically important banks this value has been increased to $9 \%$ [13]. From this point of view, when comparing Islamic and traditional banks in terms of the impact of capital adequacy on their market behavior, it was found that regulatory capital requirements have a significant impact on the lending behavior of Islamic and traditional banks. However, the change in the deposit in Islamic banks no longer depends on the level of capital adequacy. This can be explained by the fact that Islamic banks are based on assets rather than deposits in order to comply with regulatory requirements. This result shows that Islamic banks are less sensitive to market competition. Moreover, it turned out that the behavior of Islamic banks does not depend on 
the level of competition in the market and, therefore, on the interest rate. Consequently, both banking sectors behave differently, showing that Islamic banks are applying their theoretical models.

In Russian scientific studies, there are not enough works devoted to comparing the efficiency and stability of Islamic and traditional banks, which is explained by the lack of an empirical domestic basis for research. There are no Islamic financial institutions in Russia, represented by banks, insurance companies, or funds. For this reason, most scientific works are reduced to the theoretical aspects of the Islamic model of organizing financial activities and comparison with traditional banking exclusively through the specifics of their functioning $[14 ; 15]$ and a set of tools [16].

A number of domestic works question the viability of the Islamic financial model [17] and the low level of profitability of financial activities of this type of institutions [18], but foreign scientific works dispute this thesis, and the hypothesis is based on empirically proven data [19].

Descriptive analysis of various ratios of profitability, efficiency and liquidity is carried out for both categories of banks. Data analysis assumes null hypotheses that Islamic banking and traditional banking differ from each other in terms of their effectiveness. But most of the performance indicators show a positive trend for Islamic banking.

\section{Conclusions}

Islamic banks have less bargaining power than conventional banks [20]. It is also clear that both Islamic and traditional larger banks tend to take more risks, as total assets have a significant positive relationship between loan loss provisions for both types of banks. Islamic banking, however, with its religious system, allows them to have more capital and be more profitable than conventional banks, and thus have a lower reserve for possible loan losses. On the other hand, conventional banks are more efficient at controlling costs than Islamic banks and therefore have a lower reserve for possible loan losses.

The future of Islamic banking appears brighter than traditional banking, as the results show that Islamic banking is not suffering from global financial crises and economic turmoil to the extent that traditional banking is damaged.

\section{Acknowledgements}

The study was carried out with the financial support of the Russian Foundation for Basic Research within the framework of scientific project No. 18-410-200002.

\section{References}

1. ICD-REFINITIV Islamic Finance Development Report 2020. PROGRESSING THROUGH ADVERSITY. www.refinitiv.com/en/islamic-finance

2. Islamic Financial Servcies Board. 2019. Islamic Financial Services Industry Stability Report. Kuala Lumpur, Malaysia, July. http://www.ifsb.org

3. L. Baele, M. Farooq, S. Ongena, J. Bank. Financ, 44, 141, (2014)

4. A. Almansour, S. Ongena, J. Empir. Financ, 47, 78, (2018)

5. Shafron, J. Corp. Financ, 55, 6, (2019)

6. N. Bollen, J. Financ. Quant. Anal, 42, 683, (2007)

7. C. Alexakis, V. Pappas, A. J Tsikouras, Int. Financ. Mark. Institutions Money, 46, 70, (2017) 
8. A. Alhomaidi, M. Kabir Hassan, The effect of implicit market barriers on stock trading and liquidity. In: KFUPM Islamic Banking and Finance Research Conference, (2017)

9. Farag, C. Mallin, K. Ow-Yong, J. Int. Financ. Mark. Inst. Money. 54, 59, (2018)

10. M. Izzeldin, J. Johnes, S. Ongena, V. Pappas, M. Tsionas, Journal of International Financial Markets, Institutions and Money, 101279, (2020)

11. Boukhatem, F. Ben Moussa, Borsa Istanbul Review, 18, 231, (2018)

12. M.B. Archakova-Uzhakhova, Global Markets and Financial Engineering, 2, 133, (2017)

13. M.R. Tashtamirov, On the issue of approaches to the development of a differentiated methodology for regulating the activities of credit institutions in Russia, Millionshchikov-2020, 267, (2020)

14. L.V. Koch, F.G. Gasymov, Bulletin of Transbaikal State University, 11, 133, (2013)

15. N.A. Lvova, Bulletin of St. Petersburg University. Economy, 1, 100, (2013)

16. O.G. Semenjuta, E.A. Danchenko, ISJ Theoretical \& Applied Science, 06, 76, (2015)

17. T. Kuran, Christianity and Islam on Economics, 279, (2008)

18. Y. Mirkin, Russian Securities Market: Impact of Fundamental Factors, Forecast and Development Policy, M.: Alpina Pablisher, 624, (2002)

19. H. Ramlan, M.S. Adnan, Procedia Economics and Finance, 35, 359, (2016)

20. M. Tashtamirov, R. Yushaeva, Z. Tavbulatova, Z. Aylarova, Z. Tarkhanova, European Proceedings of Social and Behavioural Sciences EpSBS, 1071, (2020) 